\title{
CHANGES IN ANTIDEFLATION RESISTANCE OF CHERNOZEM TYPICAL UNDER DIFFERENT TILLAGE AND FERTILIZERS
}

O. V. PIKOVSKA, pHD, Associate Professor of Department of Soil Science and Soil Conservation named after prof. M.K.Shykula ORCID https://orcid.org/0000-0002-5052-9223

E-mail: pikovska_olena@ukr.net

National University of Life and Environmental Sciences of Ukraine

\begin{abstract}
The scale wind erosion is increasing in Ukraine in connection with the arid climate and intensive agricultural land use. Deflation causes significant damage not only to the soil cover, but also to the environment. Research has shown that the resistance of soils to deflation depends on their structural state. The aim of our work was to establish the influence of different tillage systems and fertilizers on agrophysical parameters of the soil. According to the method of dry sieving according to Savvinov, the content of particles larger than $1 \mathrm{~mm}$ and the number of agronomically valuable particles per $1 \%$ of humus according by V. V. Medvedev were determined in the soil. The research was conducted on a stationary experiment of the Department of Soil Science and Soil Conservation named prof. M. K. Shikula in Separated subdivision of NULeS of Ukraine "Oleksandr Muzychenko Velykosnytinske Educational and Research Farm" of Fastiv district of Kyiv region. The soil of the experimental site is chernozem typical.

It was found that in the variant with the application of straw, green manure and mineral fertilizers for reduced tillage, the content of particles larger than $1 \mathrm{~mm}$ was the highest and amounted to 75.1-77.5 \%. Conservation tillage systems provided a deflation-resistant soil surface, as the content of particles over $1 \mathrm{~mm}$ was greater than $60 \%$. Reduced tillage together with the fertilizer variant "Straw $1.2 t /$ ha $+N 12+N 78 P 68 K 68$ " creates the best conditions for aggregation in a layer of $0-30 \mathrm{~cm}$ of chernozem typical. On non-plowing tillage, more favorable aggregation conditions were on the variant "Straw 1.2t/ ha + green manure N12 + N78P68K68". On variant with plowing, the indicators of the structural state of chernozem typical deteriorated.
\end{abstract}

Keywords: wind erosion, lumpiness, soil structure, reduced tillage, aggregation standards, typical chernozem

Introduction.

Wind erosion is second among all soil degradation processes and causes substantial damage to agriculture (Yang, Geng, Fu, Coulter, Chai, 2020).
In the spring of 2020, an extraordinary meteorological phenomenon occurred - a powerful dust storm that covered the territory of Kyiv, Zhytomyr, Chernihiv and other regions of Ukraine. The main reason for this phenomenon 


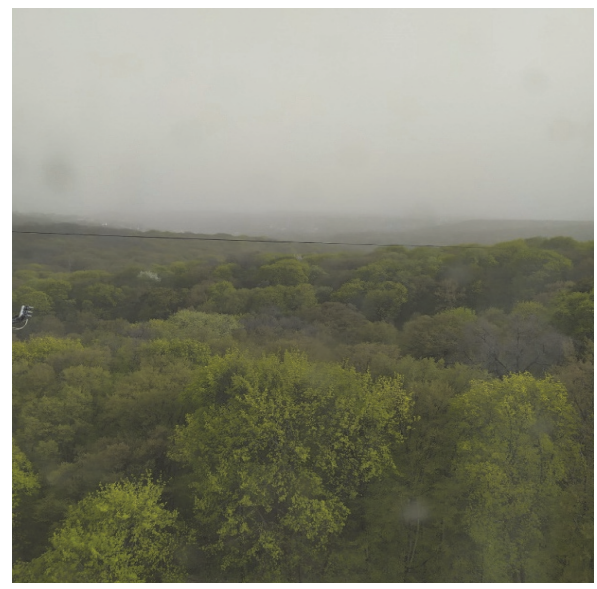

Figure 1. Dust storm in Kyiv, April 18, 2020

was the abnormal weather conditions of 2019 and the first half of 2020: insufficient rainfall in autumn and spring in combination with a snowless winter, as well as high wind speeds. is not only due to climate change. An essential factor in the occurrence of dust storms is the irrational use of soil resources. After all, the main factor in wind erosion or deflation is excessive plowing of agricultural land.

According to the the State Service of Ukraine for Geodesy, Cartography and Cadastre, as of 01.01.2016, the total area of agricultural land in Ukraine was 41.5 million hectares, including arable land 32.5 million hectares. Plowing of soils on average in Ukraine is $78.4 \%$. This is one of the highest rates in the world, which has continued to grow in recent years. At the same time, the area of forest, protective forest belts, hayfields and pastures is declining. This causes a violation of the ecological balance in agricultural landscapes, which leads to a decrease in their resistance to degradation processes, including water and wind erosion. The cause of wind erosion is the destruction of the soil structure. That is why scientific studies of soil deflation stability are important.

\section{Analysis of recent research and publications.}

Intensity of the effects of deflation processes depends on the physical and geographical conditions of the distribution of agricultural land, systematic soil protection activities and the availability of vegetation. It has been established that the acceleration of the deflation processes occurs in the territories with increased anthropogenic pressure. An understanding of soil resistance to wind erosion as affected by the integration of cropping system intensification and tillage method is imperative for reducing wind erosion, thereby improving global food security and reducing environmental degradation (Dudiak, Pichura, Potravka, Stroganov, 2020).

The intensity of deflation directly depends on the degree of wind resistance of the soil surface and wind speed. The degree of anti-deflation resistance of the upper layer is determined both directly by the stability of the soil and plant debris on its surface. (Волошенюк А.В., 2015)

Significant changes in soil aggregate size distribution associated with wind erosion processes may occur in short periods of time. Thus, temporal variability of soil surface properties, including crust and clods stability, needs to be considered in wind erosion research in agricultural soils. .(López, Gracia, Arrúe,2000)

Conservation tillage is commonly used in regions affected by water and wind erosion. Research scientists found the positive impact of reducing the intensity of tillage on fertility rates (Tan, Cao, Yuan et al., 2015; Бережняк М., Бережняк $€$., 2019;Піковська, 2011; Тихенко, 2016 ). Soil erosion estimates in the study area under conservation tillage with stubble retention was significantly lower than that under conventional tillage during the 
monitoring period. (Gao, Dang, Yu, Li, Liu, and Wang, 2016).

The size distribution and stability of soil aggregates have a major influence on the wind erodibility or soils (Tatarko, 2001). Geometric mean diameter, erodible fraction, and dry aggregate stability are soil parameters deduced by dry sieving that are used to identify soil susceptibility to wind erosion (Graciela Hevia, Mariano Mendez, Daniel Buschiazzo, 2007).

\section{Materials and methods of research.}

The research was conducted on a stationary experiment of the Department of Soil Science and Soil Conservation named prof. M. K. Shikula in Separated subdivision of NULeS of Ukraine "Oleksandr Muzychenko Velykosnytinske Educational and Research Farm" of Fastiv district of Kyiv region. The soil of the experimental site is chernozem typical. The soil of the experimental site was characterized by the following indicators. The content of physical clay in the upper horizon was $34.5 \%$, in the middle $22 \%$ of silt and $28 \%$ of sand, the content of coarse dust -46.3 , middle -6.8 , fine $-3.4 \%$. The humus content in the subsoil is $3.6 \%$, in the subsoil $-3.5 \%$. The reaction of the soil medium is neutral, the amount of absorbed cations is $35.4 \mathrm{mg}$-eq / $100 \mathrm{~g}$ of soil, and the degree of saturation of the bases is $93.4 \%$.

The experiment includes three variants of tillage:

a) plowing at $25-27 \mathrm{~cm}$;

b) deep plowless cultivation;

c) reduced tillage on deep 10-12 sm.

We researched 3 fertilization systems with the introduction of 1 ha of crop rotation area:

1. Control (without fertilizers)

2. Straw $1.2 \mathrm{t} / \mathrm{ha}+\mathrm{N} 12+\mathrm{N}_{78} \mathrm{P}_{68} \mathrm{~K}_{68}$
3. Straw $1.2 \mathrm{t} /$ ha $+\mathrm{N} 12+$ sideats + $\mathrm{N}_{78} \mathrm{P}_{68} \mathrm{~K}_{68}$.

Indicators of the structural state were determined by N. I. Savvinov, the humus content - by the method of I.V. Tyurin in the modification of V. N. Simakov. The norm of soil structure formation (aggregation) was the number of structural units (agronomically valuable structure ranging in size from 10 to 0.25 $\mathrm{mm}$ ), which accounts for $1 \%$ of the total humus (Медведєв, В. В., 2010).

Indicators of soil macrostructure, in particular the content of aggregates more than $1 \mathrm{~mm}$ in dry sieving by the method of Savvinov, are used as an indirect but universal indicator of anti-deflation resistance of soil (Чорний, Видинівська, Волошенюк, 2012; Чорний, Письменний, 2011).

The aim of our research was to establish the impact of various farming practices on structural indicators aggregate composition.

\section{Results.}

Tillage systems significantly affected the structural and aggregate composition of chernozem typical of RightBank Forest-Steppe of Ukraine. The highest content of dust particles in all variants was observed in the upper layer of $0-10 \mathrm{~cm}$, while cloddy - in the layer of $20-30 \mathrm{~cm}$ for plowing $28.2-32.4 \%$. The content of units with a size of 0.25 $0.5 \mathrm{~mm}$ is higher under plowing on all fertilizer variants.

To assess the resistance of soils to blowing on the content of particles larger than $1 \mathrm{~mm}$, the most informative is their number in the upper $0-10 \mathrm{~cm}$ layer. In our studies, their content varied significantly according to the options in the above layer and was 52-77.5\%. The lowest values were found in the control 


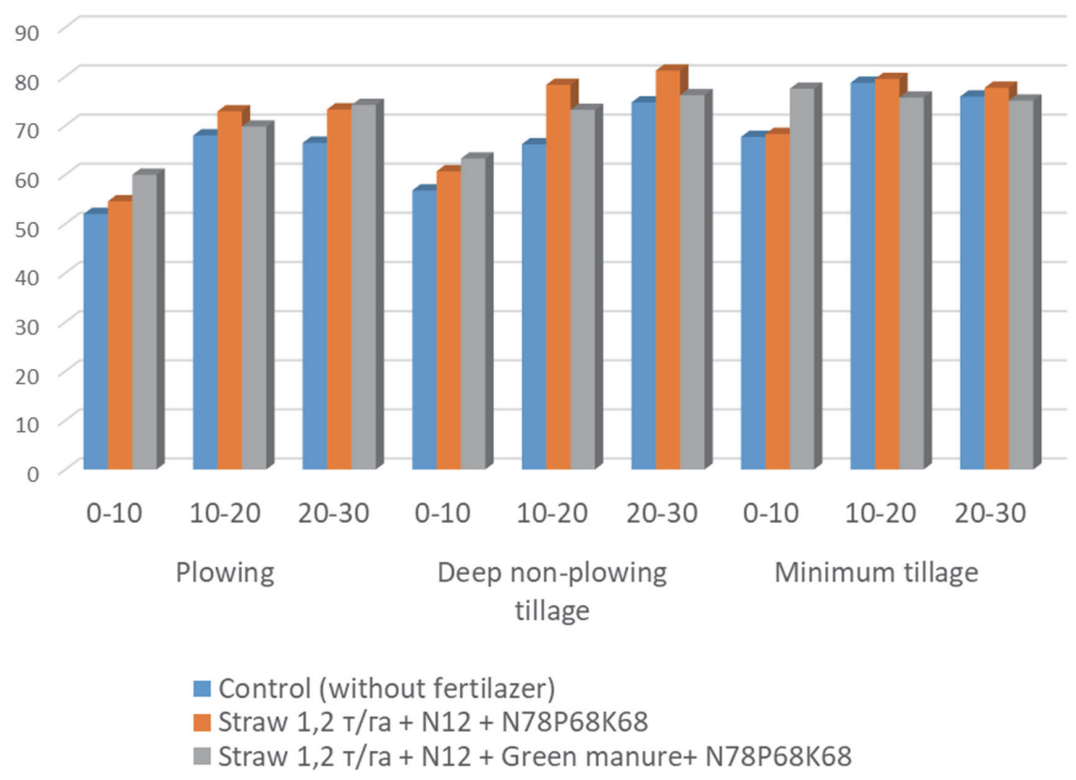

Figure 2. The content of aggregates sizes larger $1 \mathrm{~mm}$ in chernozem typical

of plowing, while on deep non-plowing tillage $-56.8 \%$. Minimization of tillage of chernozem typical helped to create conditions for the formation of a deflation-resistant soil surface even without fertilizer, where the percentage of particles over $1 \mathrm{~mm}$ was 67.7 (Figure 2).

In the layer of $10-20 \mathrm{~cm}$, similarly to the upper $0-10 \mathrm{~cm}$ layer, higher values of particles larger than $1 \mathrm{~mm}$ were observed: for deep non-plowing tillage 66.2-78.3 and for the reduced tillage $-75.7-79.5 \%$. However, in the deepest researched layer of $20-30 \mathrm{~cm}$, the advantages were for deep non-plowing tillage (74.7-81.2 \%) against $75.1-77.7 \%$ for the reduced tillage and 66.5-74.2 on plowing.

The use of organo-mineral fertilizers increased the deflation stability of the surface of chernozem typical. In the variant with the combined use of straw and mineral fertilizers, the particle content of more than $1 \mathrm{~mm}$ was higher compared to the control without fertilizer for plowing by $2.6-6.8 \%$, for deep non-plowing tillage - by 3.9-12.1\%, while under the reduced tillage increase in the percentage of particles was only $0.6-1.8$. Reduced tillage provided the best conditions for soil structuring under the influence of green manure. In the variant with the application of straw, green manure and mineral fertilizer, the content of particles larger than $1 \mathrm{~mm}$ was $75.1-77.5 \%$.

Studies on chernozem ordinary Northern Steppe of Ukraine established that the use of reduced and zero tillage ensures the preservation of their fertility. The content of aggregates larger than $1 \mathrm{~mm}$ in the $0-10 \mathrm{~cm}$ layer of ordinary chernozem at reduced tillage was $60 \%$, at No-till $-62 \%$, while during plowing the particle content was only $49 \%$. (Піковська, 2020)

Medvedev V. V. (2010) on the basis of research established a relationship between the content of agronomically valuable structural aggregates (10-0.25 $\mathrm{mm}$ ) and the content of humus in the 
soil. He recommends the use of aggregation standards for soils of Ukraine: the content of macroaggregates of 10$0.25 \mathrm{~mm}$, which is $1 \%$ of humus, in the Forest-Steppe for medium loamy soils should be $20 \%$. This level of structuring of arable soils, which is provided by the relevant aggregation factors, should be maintained and their deterioration should not be allowed. The consequence will be the reduction of aggregation agrophysical degradation, leading to deterioration of soil resistance to the action of water and wind erosion.

These V.V. Medvedev (2010) standards we use to identify potential realization of aggregation, comparing the ratio of the actual value of the index options aggregation experiment. If the actual value is less than the standards, then there are conditions in the soil that inhibit the process of aggregation. The results of calculations of indicators for different options are shown in Fig. 3.
It was found that the aggregation rate for the content of agronomically valuable aggregates for all fertilizer varients compared to plowing increased. In the case of reduced tillage, this content was the highest - 20.1-23.7, while in deep non-plowing tillage it was in the range of 18.5-22.8; for plowing the values were the lowest - 16.7-21.6\%.

The lowest values of indicators for different tillage systems were found in the layer of 0-10 sm. During plowing in almost all layers and variants of fertilizers the values were lower than the normative $20 \%$, which indicates the presence of factors that slow down the process of aggregation in the arable layer.

Deep non-plowing tillage increased the aggregation capacity of the soil on all variants of fertilizer in a layer of 0-30 $\mathrm{cm}$ compared to plowing. It should be noted that fertilizer options helped to improve soil aggregation conditions. The best conditions for aggregation

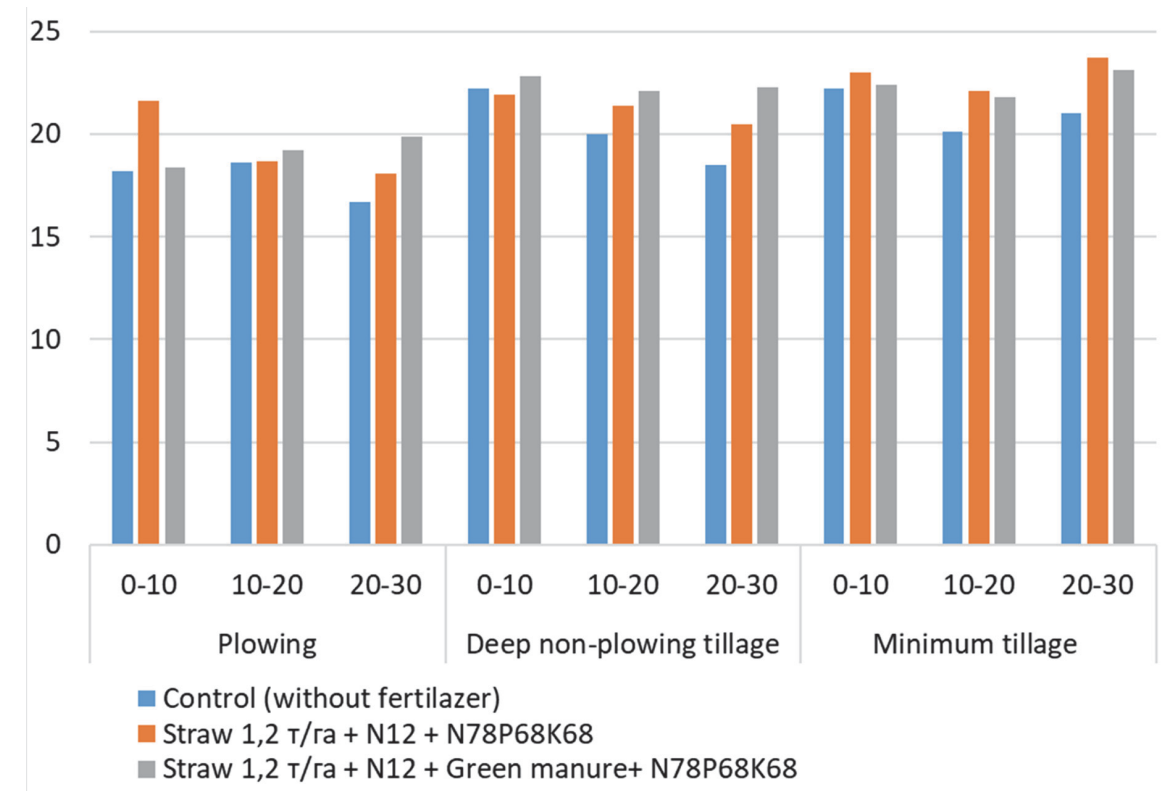

Figure 3. Content of agronomically valuable aggregates $10-0.25 \mathrm{~mm}$ per $1 \%$ of humus in chernozem typical 
in all layers of the studied soil (22.1$22.8 \%$ ) were created on the variant "Straw fertilizer $1.2 \mathrm{t} / \mathrm{ha}+\mathrm{N}_{12}+$ green manure $+\mathrm{N}_{78} \mathrm{P}_{68} \mathrm{~K}_{68}$. And for this variant of cultivation there was the smallest differentiation of soil layer 0-30 sm. In the variant of minimal tillage, some changes were noted in the variants of fertilizer compared to deep non-plowing tillage.

The highest content of aggregates with a size of $10-0.25 \mathrm{~mm}$, per $1 \%$ of humus, was observed in the variant of joint application of straw and mineral fertilizers (22.1-23.7\%). Slightly lower values of this indicator were in the case of straw, green manure and mineral fertilizers (21.8-23.1\%). We explain this phenomenon by the fact that with shallow cultivation there is a worse earning of green mass of green manure in the soil.

Thus, the application of reduced tillage in conjunction with the fertilizer option «Straw $1.2 \mathrm{t} / \mathrm{ha}+\mathrm{N} 12+\mathrm{N}_{78} \mathrm{P}_{68} \mathrm{~K}_{68}$ " creates the best conditions for aggregation in 0-30 cm layer of typical chernozem. However, with deep tillage to create favorable conditions for aggregation, we can recommend the option «Straw $1.2 \mathrm{t} / \mathrm{ha}+$ green manure $\mathrm{N}_{12}+$ $\mathrm{N}_{78} \mathrm{P}_{68} \mathrm{~K}_{68}$ ". Systematic application of plowing will worsen the structural condition of soils, especially without the use of fertilizers, which can reduce the resistance of soils to deflation.

\section{Conclusions and future perspectives.}

Irrational agricultural use of soils leads to the development of degradation processes, including wind erosion. Based on the research, it is established that tillage systems have a significant impact on the development of deflationary processes. To assess the anti-deflation stability of chernozem typical use parameters of the structural and aggregate composition of the soil. We found that the redusing of tillage together with the organo-mineral fertilizer system provides the formation of deflation-resistant surface of chernozem typical in the conditions of the Right Bank Forest-Steppe of Ukraine compared to plowing, where the content of particles larger than $1 \mathrm{~mm}$ was less than $60 \%$. Further researches on establishment of moisture-preserving effect of various systems of tillage in the conditions of aridization of climate are perspective.

\section{References}

1. Yang, C.; Geng, Y.; Fu, X.Z.; Coulter, J.A.; Chai, Q. (2020). The Effects of Wind Erosion Depending on Cropping System and Tillage Method in a Semi-Arid Region. Agronomy, 10, 732. https:// doi.org/10.3390/agronomy10050732

2. Dudiak, N., Pichura, V., Potravka, L., Stroganov, A. (2020). Spatial Modeling of the Effects of Deflation Destruction of the Steppe Soils of Ukraine. Journal of Ecological Engineering, 21(2), 166-177. https:// doi.org/10.12911/22998993/116321]

3. Voloshenyuk, A.V. (2015). Vplyv system obrobitku gruntu ta no-till na hrudkuvatist' chornozemu pivdennoho [Influence of tillage and no-till systems on the lumpiness of southern chernozem]. Taurian Scientific Bulletin. № 91. P. 24-29 http://hdl.handle. net/123456789/5687

4. López V., R. Gracia, J.L. Arrúe (2000). Effects of reduced tillage on soil surface properties affecting wind erosion in semiarid fallow lands of Central Aragón. European Journal of Agronomy, Volume 12, Issues 3-4, 191-199, https://doi.org/10.1016/S11610301(00)00046-0.

5. Tan, C., Cao, X., Yuan, S. et al. (2015). Effects of Long-term Conservation Tillage on Soil Nutrients in Sloping Fields in Regions Characterized by Water and Wind Erosion. 
Sci Rep 5, 17592. https://doi.org/10.1038/ srep17592

6. Berezhniak, M., \& Berezhniak, E. (2019). Features of the investigation of agrophysical properties of blackship by different treatment systems. Scientific journal «Plant and Soil Science», 0(294), 144-150. doi:http:// dx.doi.org/10.31548/agr2018.294.144

7. Pikovska, O. V. (2011). Structurnyi stan chornozemy zvychainogo I vmist humusu za riznykh system obrobitku. [Structural condition of chernozem common and humus content for different types of crop cultivation]. Visnyk Kharkivskoho NAUim. V. V. Dokuchayeva [Bulletin of Kharkiv NAU them V. V. Dokuchaev], 2, 56-58.

8. Tykhenko O.V. (2016) Ratsional'noye ispol'zovaniye sel'skokhozyaystvennykh zemel': problemy i perspektivy ikh resheniya [Rational use of agricultural land: problems and prospects for their solution]. Land management, cadastre and monitoring of lands. 1-2, 76-81

9. Gao, Y., Dang, X., Yu, Y., Li, Y., Liu, Y., and Wang, J. (2016). Effects of Tillage Methods on Soil Carbon and Wind Erosion. Land Degrad. Develop., 27: 583- 591. doi: 10.1002/ Idr.2404.

10. Tatarko, John (2001). Soil Aggregation and Wind Erosion: Processes and Measurements. Annals of arid zone. 40. 251-263.

11. Graciela G. Hevia, Mariano Mendez, Daniel E. Buschiazzo (2007) Tillage affects soil aggregation parameters linked with wind ero- sion. Geoderma, Volume 140, Issues 1-2, Pages 90-96,

12. Medvedyev, V. V. (2010). Imovirnisna pryroda hruntoutvorennya i yiyi naslidky dlya hruntovo-henetychnykh doslidzhen' i zemlerobs'koyi praktyky [Probabilistic nature of soil formation and its consequences for soil genetic research and agricultural practice]. Bulletin of Agrarian Science. 11. P. 9-13.

13. Chornyy S. H., Vydynivs'ka O. V., Voloshenyuk A. V. (2012). Protydeflyatsiyna efektyvnist' systemy zemlerobstva No-till $\checkmark$ umovakh pivdennoho stepu Ukrayiny. [Anti-deflation efficiency of the No-till system of agriculture in the conditions of the southern steppe of Ukraine]. Biological systems. Vol. 4. N 1. 116-119. http://ibhb. chnu.edu.ua/uploads/files/vb/BS_T4_ V1_2012/4_C_116-119_Chornyi.pdf

14. Chornyy, S. G, Pysmennyj, O. V. (2011.). Pro vzayemozvyazok mizh riznymy parametramy protydeflyacijnoyi stijkosti gruntiv Ukrayiny [About correlation between different parameters of soil wind erodibility of steppe Ukraine]. Ecology and Noospherology 22(3-4), 43-46

15. Pikovska, O. (2020). Zberezhennya rodyuchosti chornozemiv zvychaynykh $v$ umovakh arydyzatsiyi klimatu. [Conservation of fertility of chernozem ordinary in the condition of climate aridization]. Scientific journal «Plant and Soil Science», 11(1), 62-68. doi:http:// dx.doi.org/10.31548/agr2020.01.062

\section{О. В. ПіКОВСьКа (2021). ЗМІНИ ПРОТИДЕФЛЯЦІЙНОї СТІЙКОСТІ ЧОРНОЗЕМУ ТИПОВОГО ЗА РІЗНОГО ОБРОБІТКУ ҐРУНТУ ТА УДОБРЕННЯ. РLANT AND SOIL}

SCIENCE, 12(1): 86-93. https://doi.org/10.31548/agr2021.01.086

Анотація. Маситаби вітрової ерозії в Україні зростають із аридизацією клімату та інтенсивним сільськогосподарським використанням земель. Десляція завдає значної шкоди не лише грунтовому вкриттю, але й довкіллю в цілому. Дослідженнями вчених встановлено, що стійкість грунтів до дефлячії залежить від їх структурного стану.

Метою нашої роботи було встановлення впливу різних систем обробітку грунту та удобрення на агрофрізичні параметри чорнозему типового. Методом сухого просіювання 
за Саввіновим у грунті визначали вміст часток розміром понад 1 мм та кількість агрономічно-цінних часток, що припадають на 1 \% гумусу за В. В. Медведєвим.

Дослідження проводили у стаціонарному досліді кафедри грунтознавства та охорони грунтів ім. проф. М. К. Шикули у ВП нУБіП України "НДг Великоснітинське ім. О. В. Музиченка", Фастівського району, Київської області на чорноземі типовому легкосуглинковому на лесі.

Встановлено, що на варіанті із внесенням соломи, заробленням сидератів $i$ мінеральним удобренням за мілкого обробітку вміст часток понад 1 мм був найвищим і складав 75,1-77,5 \%. Безполичеві системи обробітку грунту забезпечили дефлячійно стійку поверхню грунту, адже вміст часток понад 1 мм був більш як $60 \%$. Мінімальний обробіток грунту разом із варіантом удобрення "Солома 1,2 m/ га + N12 + N78P68K68» створює найкращі умови для агрегації в шарі 0-30 см типового чорнозему. За глибокого безполицевого обробітку більш сприятливі умови агрегації були на варіанті «Солома $1,2 \mathrm{~m} /$ га + сидерат $N_{12}+N_{78} P_{68} K_{68}$ ". За оранки показники структурного стану чорнозему типового погіршувалися.

Ключові слова: вітрова ерозія, грудкуватість, структура грунту, безполицевий обробіток, нормативи агрегачії, чорнозем типовий 